\title{
Spray drying of dairy bacteria: New opportunities to improve the viability of bacteria powders
}

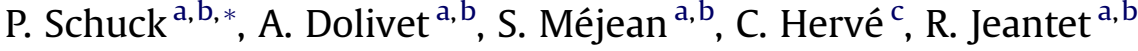 \\ a INRA, UMR 1253, F-35000 Ouest, France \\ ${ }^{\mathrm{b}}$ Agrocampus Ouest, UMR 1253, F-35000 Rennes, France \\ ${ }^{c}$ Laboratoire Standa, F-14000 Caen, France
}

\section{A R T I C L E I N F O}

Article history:

Received 27 October 2011

Received in revised form

14 December 2011

Accepted 25 January 2012

\begin{abstract}
A B S T R A C T
The most frequently used technique for dehydration of dairy bacteria is freeze drying. Of the other possible preservation techniques used in the dairy industry to produce large amounts of dairy ingredients at commercially viable processing costs, spray drying is one of the main processing tools and the cost is 10 times lower than that of freeze drying. In this work, some examples are presented for different species of dairy bacteria with respect to spray-drying processes (as an alternative approach to freeze drying) and storage conditions for production of powdered bacterial cultures with high viability (100\%) and count $\left(10^{10} \mathrm{~g}^{-1}\right)$. The advantages and disadvantages of this new approach (viability, contamination, yield during process and storage) are discussed.
\end{abstract}

(c) 2012 Elsevier Ltd. All rights reserved.

\section{Introduction}

The propionibacteria are involved in many industrial processes: e.g., production of vitamin B12 (Bullerman \& Berry, 1966; Leviton \& Hargrove, 1972) and of propionic acid (Boyaval \& Corre, 1987) and as dairy starter culture for Swiss-type cheese production (Hettinga \& Reinbold, 1972a, 1972b, 1972c). Many other uses would open up if the cost of such bacteria were lower [e.g., as silage and highmoisture grain preservation agents (Lacey, Lord, King, \& Manlove, 1978; Voelker, Casper, Lubens, \& Schingoethe, 1989), probiotics (Skupin et al., 1977) and in the production of many new and improved dairy and bakery products and processes]. The high cost is due to the time needed for the growth of these microorganisms and particularly, to the preservation method used to keep the cells alive. Freezing and freeze drying are the two main methods currently employed for such cell preservation. Spray drying is a very interesting preservation method that is already used for the preservation of yeast (Beker \& Rapoport, 1987; Elinzondo \& Labuza, 1974) and lactic acid bacteria (Espina \& Packard, 1979; Lievence, 1991). The cost of this method is more than 10 times lower than the two methods cited above (Boyaval \& Schuck, 1994). Spray drying is one of the most important industrial drying systems today. The spray dryers operating in industries from aseptic pharmaceutical

\footnotetext{
* Corresponding author. Tel.: +33 2234853 22; fax: +33223485350.

E-mail address: pierre.schuck@rennes.inra.fr (P. Schuck).
}

processing to mining operations handle feed rates from a few kilograms per hour to well over 100 tons per hour (Masters, 1991).

The versatility of the spray-drying process and the considerable progress made through technical innovation have led to greater flexibility to meet biotechnological requirements, especially low heat treatments to avoid loss of activity. Designs are available to handle toxic materials and those which require aseptic drying conditions for cell preservation. Unfortunately, the results achieved to date for spray drying of bacterial cells are very disappointing. Reports on the spray drying of bacteria are scarce when compared with those for freeze drying, partly because of the poor results obtained to date, mainly in terms of cell viability (Johnson \& Etzel, 1995). But, recently, Fu and Chen (2011) and Silva, Freixo, Gibbs, and Teixeira (2011) have realized an interesting summary of some studies on the dehydration of microorganisms by thermal process showing that the highest survival is between less than $1 \%$ and $100 \%$ dependent on the different growth media, drying media, drying systems and microorganisms. Generally, the results shown that the viability is better with Bifidobacterium than with Lactobacillus and Lactococcus. Moreover, laboratory results obtained using spraydrying apparatus cannot generally be applied to pilot or industrial scale processes because of the differences in the equipment used; resulting in considerable variations in operating parameters (Fu \& Chen, 2011; Fu, Suen, \& Etzel, 1994). Pilot spray-drying plants in which scale up is possible are very expensive.

We describe in this study a new method of spray drying of two dairy propionibacteria strains (Propionibacterium acidipropionici) in 
a pilot spray-drying plant. The microbiological characteristics and physico-chemical properties (wettability, dispersibility, solubility, water activity, glass transition, particle size distribution) of the different powders obtained were monitored for 3 years at two temperatures $\left(4^{\circ} \mathrm{C}\right.$ and laboratory room temperature, $21 \pm 2{ }^{\circ} \mathrm{C}$ ). To the best of our knowledge, this is the first report describing the feasibility of the spray drying of cells of Propionibacterium spp.

\section{Materials and methods}

\subsection{Strains}

Two strains of $P$. acidipropionici (Laboratoire Standa, Caen, France), named $A$ and $B$, were used throughout this study. The strains (A and $B$ ) were selected for possible applications in the environment and animal feed. The strains (A and B) were maintained in a Yeast Extract-Lactate medium (YEL) with glycerol $(10 \%$, $\mathrm{v} / \mathrm{v}$ ) at $-80^{\circ} \mathrm{C}$ (Malik, Reinbold, \& Vedamuthu, 1968). Three successive inoculations were carried out in the fermentation medium before inoculation of the bioreactor.

\subsection{Medium}

The medium was prepared as follows: $10 \%(\mathrm{w} / \mathrm{v})$ acid whey permeate powder (Lactalis, Mayenne, France), 2.5\% (w/v) corn steep powder (Roquette, Lestrem, France) and $1 \%(\mathrm{w} / \mathrm{v})$ yeast extract (Fould Springer, France) were dissolved in tap water. The $\mathrm{pH}$ was adjusted to 6.5 with $10 \mathrm{~m} \mathrm{NaOH}$ (Ecolab, Issy-lès-Moulineaux, France) before heat treatment $\left(1 \mathrm{~min}\right.$ at $128^{\circ} \mathrm{C}$ ) (Actijoule $32 \mathrm{~kW}$, Actini, France).

\subsection{Fermentation}

A three thousand L stainless steel tank was used as bioreactor (TL 988, Guerin, France). Four hundred litres of inoculum (A and B) were prepared in a $750 \mathrm{~L}$ bioreactor. The temperature was maintained at $30^{\circ} \mathrm{C}$ and the $\mathrm{pH}$ at $6.0 \pm 0.1$ by addition of $10 \mathrm{M} \mathrm{NaOH}$ (Ecolab, Issy-lès-Moulineaux, France). After $70 \mathrm{~h}$, the cells were collected and concentrated using an ultrafiltration device (mineral membranes, $\left(7 \mathrm{~kg} \mathrm{~mol}^{-1}\right)$ from Tami, Nyons, France, surface area of $6.65 \mathrm{~m}^{2}$ ) equipped with positive pumps. The concentrated cell suspension ( $300 \mathrm{~L}$ ) was stored at $4{ }^{\circ} \mathrm{C}$ until spray drying.

\subsection{Cell viability}

Total cell number and Propionibacterium cells were evaluated before and just after spray drying. Propionibacterium cells were enumerated on a selective medium $\left(6 \mathrm{~d}\right.$ at $\left.30^{\circ} \mathrm{C}\right)$ according to Madec, Rouault, and Maubois (1993). The cell suspension was prepared as follows: $10 \mathrm{~g}$ of powder were mixed with $90 \mathrm{~mL}$ of sterile water containing $1 \mathrm{~g}$ peptone (Difco, USA) and $8.5 \mathrm{~g} \mathrm{NaCl}$ per litre of demineralized water and adjusted to $\mathrm{pH}$ 7.0. This suspension was maintained at $37^{\circ} \mathrm{C}$ for $30 \mathrm{~min}$ then homogenized in a stomacher over 3 min (Labo. Blender 400, AJ Seward, UK). Total thermophillic and mesophilic flora were evaluated on Agar plate count medium (Difco, USA) by plating $1 \mathrm{~mL}$ of the cell suspension and incubating the Petri dishes 3 days for $55^{\circ} \mathrm{C}$ and $30^{\circ} \mathrm{C}$, respectively, according to ISO (2003). The coliforms were enumerated according to ISO (1998). Sulphite-reducing clostridia were enumerated according to the NF standard (NF, 1982).

\subsection{Spray drying}

For the experiments, $30 \mathrm{~kg}$ of concentrated cells ( $\mathrm{A}$ and $\mathrm{B}$ ) were mixed with $125 \mathrm{~kg}$ of sweet whey permeate powder (Lactalis,
Mayenne, France) and $125 \mathrm{~kg}$ of water. The concentrated microbial suspensions were spray dried in a Niro Atomizer (GEA-PE, Saint Quentin en Yvelines, France) pilot Bionov spray dryer (Rennes, France) equipped with a pressure nozzle (orifice diameter $0.73 \mathrm{~mm}$ with 4 slot core of a nominal slot width of $0.51 \mathrm{~mm}$, leading to a sprayer angle of $60^{\circ}$ ). The evaporation capacity was $70-120 \mathrm{~kg} \mathrm{~h}^{-1}$. All spray-drying parameters were constant $\left(3200 \pm 100 \mathrm{~kg} \mathrm{~h}^{-1}\right)$. The inlet air temperature was at $130 \pm 5{ }^{\circ} \mathrm{C}$, and the outlet air temperature $60 \pm 2{ }^{\circ} \mathrm{C}$, the air temperature of both sections of the vibrofluidizer (VF) (or external fluid bed) were $82 \pm 2{ }^{\circ} \mathrm{C}$, the concentrate flow rate was at $88 \pm 2 \mathrm{Lh}^{-1}$ and the air flow rate was at $3200 \pm 100 \mathrm{~kg} \mathrm{~h}^{-1}$. A new crystallizer (GEA-PE, Saint Quentin en Yvelines, France) was used before the VF, in place of the internal fluid bed, which was removed during the experiments. This device was equipped with a rotating disc $(0.2 \mathrm{rpm})$ and the air temperature in the crystallizer was approximately $25^{\circ} \mathrm{C}$. Continuous withdrawal was achieved by a collecting screw located on a radius. The powder was collected at the entrance to the vibro-fluidizer.

\subsection{Chemical analysis}

Several analyses were performed on water, support, microbial concentrates, mix and microbial powders $\left(\mathrm{pH}\right.$ at $20^{\circ} \mathrm{C}$, with a $\mathrm{pH}$ meter (Radiometer, Copenhagen, Denmark) with a combined electrode; total solid (TS) content by oven drying at $105^{\circ} \mathrm{C}$ for $7 \mathrm{~h}$ for liquids and concentrates and for $5 \mathrm{~h}$ for powders and total nitrogen matter (TNM: total nitrogen $\times 6.38$ ) according to the Kjeldahl method using the Tecator apparatus (Humeau, France)).

\subsection{Physical properties}

\subsubsection{Wettability index}

The wettability index (WI) was determined according to Haugaard Sorensen, Krag, Pisecky, and Westergaard (1978, chaps. 3 and 5). This index is the time necessary for a given weight of powder to penetrate the still surface of water. Ten grams of powder were dropped in a funnel below the surface of $100 \mathrm{~mL}$ of distilled water at $20^{\circ} \mathrm{C}$. When all the powder was wetted, the time was measured (in s) between the start and the end of the analysis. Values were determined at $\pm 1 \mathrm{~s}$. In the dairy sector, a powder is said to be wettable if its WI is lower than $60 \mathrm{~s}$.

\subsubsection{Dispersibility index}

The dispersibility index (DI) was determined according to Haugaard Sorensen et al. (1978, chaps. 3 and 5). This index represents the quantity of powder (in \%) able to pass through a sieve of $210 \mu \mathrm{m}$. Ten grams of powder were added to $100 \mathrm{~mL}$ of distilled water at $20^{\circ} \mathrm{C}$. After stirring with a spoon for $15 \mathrm{~s}$, the mixture was passed through a $210 \mu \mathrm{m}$ sieve and $1.5 \mathrm{~mL}$ of the filtrate was dehydrated by oven drying at $105{ }^{\circ} \mathrm{C}$ for $7 \mathrm{~h}$. Expressed as a \%, DI is equal to:

$\mathrm{DI}=\frac{(100+w) \cdot X_{\mathrm{DM}}}{w \cdot \frac{100-X_{\mathrm{RW}}}{100}}$

where $w$ is the weight of the powder used, $X_{\mathrm{RW}}$ the residual free water content of the powder (\% $\mathrm{w} / \mathrm{w})$ and $X_{\mathrm{DM}}$ the dry matter of the filtrate after sieving $(\%, \mathrm{w} / \mathrm{w})$.

With the result expressed to one decimal place, the standard deviation (SD) was $2 \%$.In the dairy sector, a powder is said to be dispersible if its DI is higher than $95 \%$.

\subsubsection{Solubility index}

The solubility index (SI) and insolubility index (II) were determined according to ISO (2005). This is an index (in \%) to determine 
the ability of a powder to be dissolved in water. Ten grams of powder were added to $100 \mathrm{~mL}$ distilled water at $24^{\circ} \mathrm{C}$ and blended in a glass mixing container for $90 \mathrm{~s}$. The mixed sample was poured into conical centrifuge tubes to the $50 \mathrm{~mL}$ mark and centrifuged ( $5 \mathrm{~min}, 160 \times \mathrm{g}$ ). The supernatant was siphoned off to within $5 \mathrm{~mL}$ of the surface of the sediment level. The residues were dispersed in distilled water and centrifuged again ( $5 \mathrm{~min}, 160 \times g$ ), the supernatant again being siphoned off. The insolubility index is equal to the volume of sediment $(\mathrm{mL})$ remaining after the second centrifugation from $50 \mathrm{~mL}$ of reconstituted liquid.

Expressed as a \%, SI is equal to:

$\mathrm{SI}=100-[2 \times \mathrm{II}]$

Expressed to one decimal place, the standard deviation (SD) was $2 \%$. In the dairy sector, a powder is considered soluble if its SI is higher than $99 \%$.

\subsubsection{Water activity}

Water activity $\left(a_{\mathrm{w}}\right)$ was measured in triplicate with a Novasina water activity meter (RTD-33 TH-2, Pfäffikon, Switzerland) at a constant temperature of $25^{\circ} \mathrm{C}$.

\subsubsection{Particle size distribution}

Particle size distributions were determined by static light scattering (Mastersizer S, Malvern Instruments Ltd., Malvern, UK) with a $5 \mathrm{~mW} \mathrm{He}-\mathrm{Ne}$ laser operating at a wavelength of $632.8 \mathrm{~nm}$ with a $300 \mathrm{~F}$ lens. Size distributions were determined using a dry powder feeder attachment and the standard optical model for presentation of particles dispersed in air was used. The results obtained were average diameters calculated from Mie theory (mean of three analyses). The criterion selected was $d(0.50)$, meaning that $50 \%$ of the particles had diameters smaller than this criterion. The method of Gaiani et al. (2010) was used.

\subsubsection{Glass transition temperatures $\left(\mathrm{T}_{g}\right)$}

Glass transition temperatures $\left(T_{\mathrm{g}}\right)$ and heat capacity changes $\left(\Delta C_{\mathrm{p}}\right)$ were determined by differential scanning calorimetry (DSC) (Q-1000, TA Instruments, Saint Quentin en Yvelines, France) calibrated with indium (melting point $156.6^{\circ} \mathrm{C}$ ). This method was described by Schuck et al. (2005) with the following modifications. The samples were scanned twice to eliminate the hysteresis effect of thermal relaxation that is typical of glass transition. The initial scanning rate was $5{ }^{\circ} \mathrm{C} \mathrm{min}^{-1}$ from $-20^{\circ} \mathrm{C}$ to $+70{ }^{\circ} \mathrm{C}$. Samples were cooled at $10^{\circ} \mathrm{C} \mathrm{min}^{-1}$ to $-20^{\circ} \mathrm{C}$, and the $T_{\mathrm{g}}$ range was determined from the DSC curve of the second scan at $5^{\circ} \mathrm{C} \mathrm{min}^{-1}$ from $-20{ }^{\circ} \mathrm{C}$ to $+140{ }^{\circ} \mathrm{C}$, giving three values: $T_{\mathrm{g}}$ onset $\left(T_{\mathrm{go}}\right), T_{\mathrm{g}}$ inflection $\left(T_{\mathrm{gi}}\right)$ and $T_{\mathrm{g}}$ endset $\left(T_{\mathrm{ge}}\right) . \Delta C_{\mathrm{p}}$ values were established according to the change in heat capacity between $T_{\text {go }}$ and $T_{\text {ge. }}$.

\subsubsection{Powder preservation}

Samples of each powder ( $500 \mathrm{~g})$ were analyzed immediately after spray-drying day $(\mathrm{D}+0)$ and over storage time $(\mathrm{D}+4,+12,+18,+25,+51,+106,+176,+385,+1121)$ in order to study the keeping properties of these powders. Storage conditions were either $4 \pm 0.5^{\circ} \mathrm{C}$ with a relative humidity of $75 \pm 3 \%$ or room temperature $\left(21 \pm 3^{\circ} \mathrm{C}\right)$ with a relative humidity of $45 \pm 10 \%$.

\section{Results and discussion}

\subsection{Physico-chemical properties}

Table 1 shows the results of the physico-chemical analysis of each sample during the process. The TS (total solid) content of the 2 concentrates with cell suspensions A and B was around $44 \%$. The total nitrogen matter (TNM) of the 2 types of final bacteria powder (A and B), was low (between $5.8 \%$ for B and $6.8 \%$ for A); corresponding to the low TNM in the UF permeate powder. The moisture content and $a_{\mathrm{w}}$ of the 2 types of bacterial powder (A and B) were 2.2\% (A) and 3.3\% (B), and 0.17 (A) and 0.19 (B), respectively. The glass transition temperature $\left(T_{\mathrm{g}}\right)$ and heat specific capacity $\left(\Delta C_{\mathrm{p}}\right)$ were $43{ }^{\circ} \mathrm{C}(\mathrm{A}), 41^{\circ} \mathrm{C}(\mathrm{B})$ and $0.27 \mathrm{Jg}^{-1}{ }^{\circ} \mathrm{C}^{-1}(\mathrm{~A}), 0.24 \mathrm{~J} \mathrm{~g}^{-1}{ }^{\circ} \mathrm{C}^{-1}(\mathrm{~B})$. The moisture content, $a_{\mathrm{w}}, T_{\mathrm{g}}$ and $\Delta C_{\mathrm{p}}$ were compatible with optimal storage conditions $\left(T_{\mathrm{g}}>\right.$ storage temperature and $a_{\mathrm{w}}$ between 0.18 and 0.22) (Efstathiou, Feuardent, Mejean, \& Schuck, 2002; Labuza, 1975; Schuck et al., 2005; Schuck, Méjean, Dolivet, Jeantet, \& Bhandari, 2007).

Table 1 shows that the particle size distribution was around $100 \mu \mathrm{m}$ for both types of final bacteria powder, which is a classical size for dairy powders (Pisecky, 1997, chaps. 10 and 12). According to the dairy sector, the rehydration behaviour showed that the 2 types of bacteria powder were soluble ( $\mathrm{SI}>99.0 \%$ ) and wettable (WI $<60$ s) but not that much dispersible ( $72 \%$ for A and $64 \%$ for B). The most important result was that the powders were soluble and wettable for rehydration. The dispersibility index (DI) is often considered as an important characteristic in order to decide whether a product is instant or not on the basis of a single property, whatever the SI and WI values (Pisecky, 1997, chaps. 10 and 12). This was not the most important characteristic for this study.

Table 1

Physico-chemical analyses of each sample throughout the process, from the liquid to the powder. ${ }^{\mathrm{a}}$

\begin{tabular}{|c|c|c|c|c|c|c|c|c|c|c|}
\hline Sample & $\mathrm{pH}$ & TNM (\%) & TS (\%) & $a_{\mathrm{w}}$ & $d(0.5)(\mu \mathrm{m})$ & $\mathrm{SI}(\%)$ & DI (\%) & WI (\%) & $T_{g}\left({ }^{\circ} \mathrm{C}\right)$ & $\Delta C_{\mathrm{p}}\left(\mathrm{Jg}^{-1}{ }^{\circ} \mathrm{C}^{-1}\right)$ \\
\hline Water & nd & nd & nd & nd & nd & nd & nd & nd & nd & nd \\
\hline UF permeate powder & nd & $6.1 \pm 0.1$ & $98.1 \pm 0.1$ & $0.20 \pm 0.02$ & $120 \pm 4$ & $>99.0 \pm 0.0$ & $77.0 \pm 2.2$ & $>60 \pm 0$ & $20 \pm 2$ & $0.11 \pm 0.01$ \\
\hline UF permeate powder + water & $5.95 \pm 0.03$ & $3.0 \pm 0.0$ & $48.8 \pm 0.0$ & nd & nd & nd & nd & nd & nd & nd \\
\hline Bacteria A & $6.45 \pm 0.01$ & $2.2 \pm 0.0$ & $3.4 \pm 0.0$ & nd & nd & nd & nd & nd & nd & nd \\
\hline $\begin{array}{l}\text { UF permeate powder }+ \text { water } \\
\quad+\text { bacteria }\end{array}$ & $5.88 \pm 0.02$ & $3.0 \pm 0.0$ & $44.0 \pm 0.0$ & nd & nd & nd & nd & nd & nd & nd \\
\hline Powder on crystallizer (A) & nd & nd & $88.1 \pm 0.1$ & $0.43 \pm 0.02$ & nd & nd & nd & nd & $15 \pm 3$ & $0.51 \pm 0.03$ \\
\hline Powder before VF (A) & nd & $6.6 \pm 0.1$ & $97.1 \pm 0.1$ & $0.19 \pm 0.01$ & $81 \pm 3$ & $>99.0 \pm 0.0$ & $67.0 \pm 1.5$ & $29 \pm 1$ & $42 \pm 2$ & $0.19 \pm 0.01$ \\
\hline Powder after VF (Final) (A) & nd & $6.8 \pm 0.1$ & $97.8 \pm 0.1$ & $0.17 \pm 0.02$ & $101 \pm 3$ & $>99.0 \pm 0.0$ & $72.0 \pm 1.6$ & $14 \pm 1$ & $43 \pm 1$ & $0.27 \pm 0.02$ \\
\hline Bacteria B & $6.31 \pm 0.03$ & $2.4 \pm 0.1$ & $3.8 \pm 0.0$ & nd & nd & nd & nd & nd & nd & nd \\
\hline $\begin{array}{l}\text { UF permeate powder }+ \text { water } \\
\quad+\text { bacteria }\end{array}$ & $5.89 \pm 0.03$ & $2.9 \pm 0.0$ & $43.6 \pm 0.0$ & nd & nd & nd & nd & nd & nd & nd \\
\hline Powder on crystallizer (B) & nd & nd & $87.1 \pm 0.1$ & $0.48 \pm 0.02$ & nd & nd & nd & nd & $16 \pm 3$ & $0.53 \pm 0.03$ \\
\hline Powder before VF (B) & nd & $5.9 \pm 0.0$ & $96.0 \pm 0.1$ & $0.21 \pm 0.02$ & $83 \pm 4$ & $>99.0 \pm 0.0$ & $56.0 \pm 2.8$ & $24 \pm 1$ & $37 \pm 2$ & $0.24 \pm 0.02$ \\
\hline Powder after VF (final) (B) & nd & $5.8 \pm 0.1$ & $96.7 \pm 0.1$ & $0.19 \pm 0.01$ & $100 \pm 3$ & $>99.0 \pm 0.0$ & $64.0 \pm 1.7$ & $17 \pm 1$ & $41 \pm 2$ & $0.24 \pm 0.01$ \\
\hline
\end{tabular}

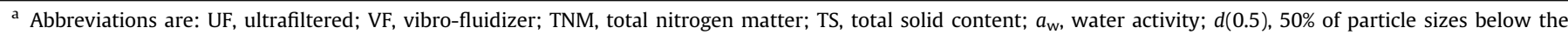
indicated value; SI, solubility index; DI, dispersibility index; WI, wettability index; $T_{\mathrm{g}}$, glass transition temperature; $\Delta C_{\mathrm{p}}$, heat specific capacity; nd, not determined. 
Table 2

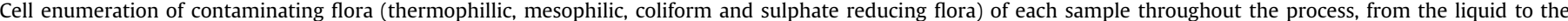
powder. $^{\mathrm{a}}$

\begin{tabular}{|c|c|c|c|c|}
\hline Sample & $\begin{array}{l}\text { Thermophillic } \\
\text { flora }\left(\log \mathrm{cfu} \mathrm{g}^{-1}\right)\end{array}$ & $\begin{array}{l}\text { Mesophilic } \\
\text { flora }\left(\log \mathrm{cfu} \mathrm{g}^{-1}\right)\end{array}$ & $\begin{array}{l}\text { Coliform flora } \\
\left(\log \mathrm{cfu}^{-1}\right)\end{array}$ & $\begin{array}{l}\text { Sulphate reducing } \\
\text { flora }\left(\log \text { cfu } 10 \mathrm{~g}^{-1} \text { ) }\right.\end{array}$ \\
\hline Water & nd & nd & nd & nd \\
\hline UF permeate powder & 3.6 & 2.2 & nd & 0.0 \\
\hline UF permeate powder + water & 3.2 & 2.2 & nd & 0.6 \\
\hline Bacteria A & 1.1 & 0.0 & nd & 0.0 \\
\hline UF permeate powder + water + bacteria & 2.8 & 1.4 & nd & 0.3 \\
\hline Powder before VF $(A)$ & 3.1 & 2.0 & nd & 0.3 \\
\hline Powder after VF (final) (A) & 3.5 & 2.0 & nd & 0.9 \\
\hline Bacteria B & 0.0 & 0.7 & nd & 0.0 \\
\hline UF permeate powder + water + bacteria & 3.1 & 1.8 & nd & 0.0 \\
\hline Powder before VF (B) & 3.2 & 2.1 & nd & 0.6 \\
\hline Powder after VF (final) (B) & 3.2 & 2.2 & nd & 0.8 \\
\hline
\end{tabular}

${ }^{a}$ Abbreviations are: UF, ultrafiltered; VF, vibro-fluidizer; cfu, colony-forming unit; nd, not detected.

\subsection{Microbial results}

Table 2 shows the values of the enumeration of contaminating microflora (except Propionibacterium). The values (expressed in $\log \mathrm{cfu} \mathrm{g}^{-1}$ ) were $3.5(\mathrm{~A})$ and $3.2(\mathrm{~B})$ for thermophillic flora, $2.0(\mathrm{~A})$ and $2.2(\mathrm{~B})$ for mesophilic flora, and $0.9(\mathrm{~A})$ and $0.8(\mathrm{~B})$ for sulphate reducing flora. No coliforms were detected in the bacteria powder. Table 2 shows that the major source of contamination was due to the UF permeate powder. We therefore propose that for further experiments, it would be interesting to perform a heat treatment or microfiltration $(1.4 \mu \mathrm{m})$ on the UF permeate powder + water mixture to remove bacterial contamination.

Table 3 shows the enumeration of Propionibacterium, expressed in $\log \mathrm{cfu} \mathrm{g}^{-1}$, in $\log \mathrm{cfu} \mathrm{g}^{-1}$ total solid (TS) content and in \% of survival. The Propionibacterium population in the feed suspension was between $10.4 \log \mathrm{cfu} \mathrm{g}^{-1}$ (A) and $10.9 \log \mathrm{cfu} \mathrm{g}^{-1}$ (B), representing a high cell concentration. These values were decreased in the UF permeate + water + bacteria mixture partly due to the dilution $(1.1 \log )$ and partly due to the osmotic pressure stress of the cell in the UF powder + water mixture to reach $10.1 \log \mathrm{cfu} \mathrm{g}^{-1}$ TS (A) and $9.5 \log$ cfu g $^{-1}$ TS (B); these cell concentrations were further considered as reference values for the determination of the percentage of survival after spray drying. Thus, after the 1 st step of spray drying including the crystallizer, before drying on vibrofluidizer (VF) and after drying on VF, no decimal reductions were measured in powder A or B, achieving a survival level of $100 \%$ for both strains with a high Propionibacterium concentration at $10.4 \log \mathrm{cfu} \mathrm{g}^{-1}$ (A) and $10.7 \log \mathrm{cfu} \mathrm{g}^{-1}$ (B) (Table 3). These excellent results were due to the specific spray-drying process achieved, which included the crystallizer step between the bottom of the spray dryer and the VF. This device made it possible to spray dry at a low outlet air temperature $\left(60^{\circ} \mathrm{C}\right)$ to produce a powder with a high-moisture content (12-13\%) and high $a_{\mathrm{w}}\left(0.43-0.48\right.$ at $\left.25^{\circ} \mathrm{C}\right)$ and a low $T_{\mathrm{g}}\left(-15\right.$ to $-16^{\circ} \mathrm{C}$ ) (Table 1$)$. According to Roos (1997, 2002 ), the lactose can crystallize in around $2 \mathrm{~min}$ in $\beta$-form when the difference between powder temperature and product $T_{\mathrm{g}}$ is about $40{ }^{\circ} \mathrm{C}$; in our experiments, the difference between the air temperature around the powder $\left(25^{\circ} \mathrm{C}\right)$ and the $T_{\mathrm{g}}\left(-15^{\circ} \mathrm{C}\right.$ for powder A) combined with the residence time of the powder in the crystallizer (fixed at $5 \mathrm{~min}$ ) was in accordance with this hypothesis. Thus, after one rotation of the crystallizer, the lactose crystallized, thereby improving the flowability of the bacteria powder, which is compatible with the next step, i.e., post drying in a VF, and led to a limitation of an excessive moisture content thus limiting the destruction of bacteria in the powder (Vuataz, 2002). The same strain was tested with the same process parameters but without the crystallizer to obtain a decimal reduction between 3 and 5 (not shown and not published). Other strains (Bifidobacterium) were tested with the same process and with the crystallizer to obtain also the same decimal reduction (3-5) (not shown and not published).

\subsubsection{Storage conditions}

Table 4 presents the cell viability of the powders for up to 1121 days at $4{ }^{\circ} \mathrm{C}$ and room temperature. The level of viability of the Propionibacterium powder remained not significantly changed after $25 \mathrm{~d}$ storage, whatever the type of bacteria and the temperature of storage, before and after the VF.

\subsubsection{Powder after crystallizer and before vibro-fluidizer}

After $25 \mathrm{~d}$, cell viability decreased more quickly in the powder stored at room temperature before the $\mathrm{VF}$, probably due to a slightly higher moisture content and $a_{\mathrm{w}}$ (Table 1 ) than in the powder after the $\mathrm{VF}$, hence the need to finish drying the excess moisture of the powder issuing from the crystallizer on a VF (or external fluid bed). At $4{ }^{\circ} \mathrm{C}$, there was no decimal reduction for these powders until

Table 3

Cell enumeration of Propionibacterium and \% of survival of each sample throughout the process, from the liquid to the powder. ${ }^{\mathrm{a}}$

\begin{tabular}{|c|c|c|c|}
\hline Sample & Propionibacterium flora $\left(\log \mathrm{cfu}^{-1}\right)$ & Propionibacterium flora $\left(\log \mathrm{cfu} \mathrm{g}^{-1} \mathrm{TS}\right)$ & Survival (\%) \\
\hline Bacteria A & 10.4 & 11.9 & - \\
\hline UF permeate powder + water + bacteria & 9.7 & 10.1 & - \\
\hline Powder before VF (A) & 10.5 & 10.5 & 100 \\
\hline Powder after VF (final) (A) & 10.4 & 10.4 & 100 \\
\hline Bacteria B & 10.9 & 12.4 & - \\
\hline UF permeate powder + water + bacteria & 9.1 & 9.5 & - \\
\hline Powder before VF (B) & 10.6 & 10.7 & 100 \\
\hline Powder after VF (final) (B) & 10.7 & 10.7 & 100 \\
\hline
\end{tabular}

\footnotetext{
${ }^{a}$ Abbreviations are: UF, ultrafiltered; VF, vibro-fluidizer; cfu, colony-forming unit; TS, total solids.
} 
Table 4

Cell viability of bacteria powders according to storage conditions (room temperature and $4{ }^{\circ} \mathrm{C}$ ) on 2 species of bacteria (A and B) before and after vibro-fluidizer (VF).

\begin{tabular}{|c|c|c|c|c|c|c|c|c|}
\hline \multirow[t]{3}{*}{ Days storage } & \multicolumn{4}{|l|}{ A } & \multicolumn{4}{|l|}{ B } \\
\hline & \multicolumn{2}{|c|}{ Powder before VF } & \multicolumn{2}{|c|}{ Powder after VF (final) } & \multicolumn{2}{|c|}{ Powder before VF } & \multicolumn{2}{|c|}{ Powder after VF (final) } \\
\hline & Room temp. & $4^{\circ} \mathrm{C}$ & Room temp. & $4^{\circ} \mathrm{C}$ & Room temp. & $4^{\circ} \mathrm{C}$ & Room temp. & $4{ }^{\circ} \mathrm{C}$ \\
\hline 4 & 10.5 & 10.4 & 10.4 & 10.4 & 10.6 & 10.6 & 10.6 & 10.6 \\
\hline 12 & 10.4 & 10.4 & 10.4 & 10.5 & 10.7 & 10.7 & $\mathrm{nd}^{\mathrm{a}}$ & 10.7 \\
\hline 18 & 10.4 & 10.6 & nd & 10.5 & nd & 10.8 & nd & nd \\
\hline 25 & 9.7 & 10.5 & 10.2 & 10.5 & 10.6 & 10.7 & 10.6 & 10.7 \\
\hline 51 & 8.1 & 10.6 & 10.0 & 10.5 & 10.5 & 10.8 & 10.5 & 10.6 \\
\hline 106 & nd & 10.1 & 8.5 & 10.1 & 9.6 & 10.3 & 10.8 & 10.3 \\
\hline 176 & 5.9 & 10.2 & nd & 10.2 & nd & 10.4 & 9.4 & 10.3 \\
\hline 385 & nd & 9.7 & nd & 9.8 & nd & 10.2 & nd & nd \\
\hline 1121 & nd & 8.1 & nd & 7.1 & nd & 9.6 & nd & 9.7 \\
\hline
\end{tabular}

a nd, Not determined.

$176 \mathrm{~d}$ for A and $385 \mathrm{~d}$ for B, despite the slightly higher $a_{\mathrm{w}}$ and moisture content than the final powder. It was due to the low storage temperature limiting the loss of bacteria.

\subsubsection{Powder after vibro-fluidizer (final powder)}

There was no decimal reduction for the storage of the final powder, after $51 \mathrm{~d}$ and $106 \mathrm{~d}$ at room temperature for bacteria $\mathrm{A}$ or $\mathrm{B}$, respectively, or after $176 \mathrm{~d}$ at $4{ }^{\circ} \mathrm{C}$ for bacteria $\mathrm{A}$ and $\mathrm{B}$. After $1121 \mathrm{~d}$ at $4{ }^{\circ} \mathrm{C}$, the decimal reduction was 3 for bacteria A but only 1 for bacteria $B$. The results therefore showed that depending on the type of bacteria (A or B), if the moisture content and $a_{\mathrm{w}}$ are optimal, it is possible to store bacteria powder at room temperature and even better at $4{ }^{\circ} \mathrm{C}$ in good conditions to avoid decimal reduction for a long period. Laroche, Fine, and Gervais (2005) have shown that the optimal $a_{\mathrm{w}}$ regarding to the viability is between 0.3 and 0.5 and the lowest viability occurs when the $a_{\mathrm{w}}$ is lower than 0.1 . The $a_{\mathrm{w}}$ of bacteria powders A and B are close to 0.2 , avoiding in parallel the Maillard reaction and caking that start at 0.3 of $a_{\mathrm{w}}$ (Labuza, 1975). Thus the good results of viability during storage could be explained by the storage temperature and by an $a_{\mathrm{w}}$ close to the optimal value.

\section{Conclusions}

We showed in this study that it is possible to produce a spray dried bacteria powder using a less expensive process (about 10 times less) than freeze drying with a high level of cells $\left(>10^{10} \mathrm{cfu}^{-1}\right)$ and high viability during the process and during storage. The process is not yet optimal, because the use of low air temperatures during spray-drying results in high stickability of the powder, thus decreasing the powder production yield $(<50 \%$ against $99 \%$ on skim milk powder). However, new equipment will be tested in further study to replace the crystallizer by a belt before the VF to avoid stickiness in the chamber, without changing the spray-drying parameters. The process that we tested also depends on the type of bacteria and probably also on stress generated during the process. Nevertheless, we showed that spray drying may be an alternative to freezing or freeze drying for producing powders with viable varying levels of bacteria (viability $>95 \%$ ) over a long time (several months) at room temperature and longer at $4{ }^{\circ} \mathrm{C}$. Improvements in the bacteria (type, resistance to stress, temperature, etc.), and in the process (air treatment, sterilization of the support and introduction of a belt in the place of the crystallizer, before the VF) should improve the effectiveness of the drying of dairy bacteria.

\section{References}

Beker, M. J., \& Rapoport, A. (1987). Conservation of yeasts by dehydration. Advances in Biochemical Engineering/Biotechnology, 32, 127-171.
Boyaval, P., \& Corre, C. (1987). Continuous fermentation of sweet whey permeate for propionic acid production in a CSTR with UF recycle. Biotechnology Letters, 9, 801-806.

Boyaval, P., \& Schuck, P. (1994). Le séchage des microorganismes par atomisation. Industries Alimentaires et Agricoles, 111, 807-818.

Bullerman, L. B., \& Berry, E. C. (1966). Use of cheese whey for vitamin B12 production. Applied Microbiology, 14, 553-557.

Efstathiou, T., Feuardent, C., Mejean, S., \& Schuck, P. (2002). The use of carbonyl analysis to follow the main reactions involved in the process of deterioration of dehydrated dairy products: prediction of most favourable degree of dehydration. Lait, 82, 423-439.

Elinzondo, H., \& Labuza, T. P. (1974). Death kinetics of yeast in spray-drying. Biotechnology and Bioengineering, 26, 1245-1259.

Espina, F., \& Packard, V. S. (1979). Survival of Lactobacillus acidophilus in a spraydrying process. Journal of Food Protection, 42, 149-152.

Fu, N., \& Chen, X. D. (2011). Towards a maximal cell survival in convective thermal drying process. Food Research International, 44, 1127-1149.

Fu, W. Y., Suen, S. Y., \& Etzel, M. R. (1994). Injury to Lactococcus lactis subsp. lactis C2 during spray-drying. In V. Rudolph, \& R. B. Keey (Eds.), Drying $94 \mathrm{vol}$. B, proceedings international drying symposium (pp. 785-792). Gold Coast, Australia.

Gaiani, C., Arab Therany, E., Morand, M., Jacquot, M., Schuck, P., Jeantet, R., et al. (2010). How surface composition of high milk proteins powders is influenced by spray-drying temperature. Colloids and Surfaces B: Biointerfaces, 75, 377-384.

Haugaard Sorensen, I., Krag, J., Pisecky, J., \& Westergaard, V. (1978). Méthodes d'analyses des produits laitiers déshydratés. Copenhagen, Denmark: Niro A/S.

Hettinga, D. H., \& Reinbold, G. W. (1972a). The propionic acid bacteria. A review. I. Growth. Journal of Milk and Food Technology, 35, 295-301.

Hettinga, D. H., \& Reinbold, G. W. (1972b). The propionic acid bacteria. A review. II. Metabolism. Journal of Milk and Food Technology, 35, 358-372.

Hettinga, D. H., \& Reinbold, G. W. (1972c). The propionic acid bacteria. A review. III. Miscellaneous metabolic activities. Journal of Milk and Food Technology, 35, 436-447.

ISO. (1998). Milk and milk products - Enumeration of coliforms. ISO standards 4831 and 4832. Geneva, Switzerland: ISO.

ISO. (2003). Milk and milk products - Enumeration of microorganisms. ISO standard 4833. Geneva, Switzerland: ISO.

ISO. (2005). Dried milk and dried milk products - Determination of insolubility index. ISO standard 8156. Geneva, Switzerland: ISO.

Johnson, J. A. C., \& Etzel, M. R. (1995). Properties of Lactobacillus helveticus CNRZ 32 attenuated by spray-drying, freeze-drying or freezing. Journal of Dairy Science, 78, 761-768.

Labuza, T. P. (1975). Sorption phenomena in foods: theoretical and practical aspects In C. K. Rha (Ed.), Theory, determination and control of physical properties of food materials. Dordrecht, Germany: Reidel Hahn.

Lacey, J., Lord, K. A., King, H. G. C., \& Manlove, R. (1978). Preservation of baled hay with propionic and formic acids and a proprietary additive. Annals of Applied Biology, 88, 65-73.

Laroche, C., Fine, F., \& Gervais, P. (2005). Water activity affects heat resistance of microorganisms in food powders. International Journal of Food Microbiology, 97, 307-315.

Leviton, A., \& Hargrove, R. E. (1972). Microbiological synthesis of vitamin B12 by propionic acid bacteria. Industrial and Engineering Chemistry, 44, 2651-2655.

Lievence, L. C. (1991). The inactivation of Lactobacillus plantarum during drying. Ph.D. thesis, University of Wageningen, The Netherlands.

Madec, M. N., Rouault, A., \& Maubois, J. L. (1993). Milieu sélectif et procédé pour le dénombrement des bactéries propionioques. French patent no. 9300823.

Malik, A. C., Reinbold, G. W., \& Vedamuthu, E. R. (1968). An evaluation of the taxonomy of Propionibacterium. Canadian Journal of Microbiology, 14, 1185-1191.

Masters, K. (1991). Spray-drying handbook (5th ed.). London, UK: Longman Scientific and Technical Press.

NF. (1982). Edible gelatine - Enumeration of sulfito-reducing anaerobic microorganism spores - Anaerobic colony count technique at $37^{\circ} \mathrm{C}$. NF V59-106. 
Pisecky, J. (1997). Handbook of milk powder manufacture. Copenhagen, Denmark: Niro A/S.

Roos, Y. H. (1997). Water in milk products. In P. F. Fox (Ed.), Advanced dairy chemistry, Vol. 3 (pp. 303-346). London, UK: Chapman \& Hall.

Roos, Y. H. (2002). Importance of glass transition and water activity to spray drying and stability of dairy powders. Lait, $82,478-484$.

Schuck, P., Blanchard, E., Dolivet, A., Méjean, S., Onillon, E., \& Jeantet, R. (2005) Water activity and glass transition in dairy ingredients. Lait, 85, 295-304.

Schuck, P., Méjean, S., Dolivet, A., Jeantet, R., \& Bhandari, B. (2007). Keeping quality of dairy ingredients. Lait, $87,481-488$.
Silva, J., Freixo, R., Gibbs, P., \& Teixeira, P. (2011). Spray-drying for the production of dried cultures. International Journal of Dairy Technology, 64, 321-335.

Skupin, J., Pedziwilk, F., Giec, A., Nowakowska, K., Trajanowska, K., \& Jaszewski, B. (1977). Nutritive value of Propionibacteria and lactose-fermenting yeast grown in whey. Journal of Food Processing and Preservation, 1, 207-216.

Voelker, H. H., Casper, D. P., Lubens, F. C., \& Schingoethe, D. J. (1989). High moisture corn preserved with esters of propionic acid for lactating cows. Journal of Dairy Science, 72, 89-92.

Vuataz, G. (2002). The phase diagram of milk: a new tool for optimising the drying process. Lait, 82 , 485-500. 